big advance on the traditional technique of applying a static seismic coefficient. The computer is being modified to allow for multi-storey yield.

A major addition to the equipment used in the aurorál programme has been the auroral radar set up at Arrival Heights close to Scott Base, and the unmanned automatic observatory operating for a year near Becks in Central Otago has demonstrated the superiority of conditions there for all aspects of the optical work. The Geophysical Observatory has made a special investigation of the New Zealand ionospheric data to meet requests made by the Post and Telegraph Department, and a detailed magnetic survey was made on the aircraft compass-swinging site at Wellington Airport ; this was to ensure that the area was free from magnetic effects due to buried ferro-magnetic materials that might affect aircraft compasses. Considerable attention has been directed to modern map-preparation techniques and procedures in cartography, and a major activity of the Antarctic programme has been the continuation of the geological and topographical survey of the Ross Dependency begun by parties from the transAntarctic Expedition. A major step forward in pollen research in New Zealand will be the publication this year of a Geological Survey Palaeontological Bulletin recording the important results of a new phase of the work-the successful extraction of pollen from marine sedimentary rocks.

In the past year the New Zealand benthic survey has concentrated on the west coast of the North Island and the western approaches to Cook Strait, and the survey is also building up collections of marine bottom fauna from which the common New Zealand species, and many of the rarer ones can be identified and described. Work on the design of a gas-pressure alarm system in telephone cables led to a method of calculating the required shapes of the pressure waves for a cable of given permeability to the gas for any size of puncture. At the Dominion
Physical Laboratory the internodal cell of the alga Nitella is being used for an investigation of cell wall growth. Work has been carried out on the growth of Pittomyces chartarum on various synthetic media, and on the influence of different factors on the production of spores, while the fatty acid composition of this and related species has been determined and a systematic investigation made of the anti-fungal substances in sweet vernal and red clover.

Much of the development programme at the Keikohe sub-station of the Grasslands Division has been concerned with the typical heavy clay 'gumland', which is very acid, extremely low in plant foods and has a typical 'gumland' cover of stunted manuka and rushes. Heavy dressings of lime, phosphate and potash at the time of sowing gave spectacular results. Work on the South Island tussock grasslands has revealed two undescribed and widespread grassland associations of botanical and economic importance. Two high-yielding varieties of potato have been bred which appear to combine resistance to wind and drought with resistance to late blight, and use of systemic insecticides has opened up possibilities of producing better seed potatoes in areas such as Lincoln, where aphid numbers are high for only short periods. By use of stickers and cultures with a high bacterial count, nodule bacteria have been held on lucerne seed in a viable condition for at least four weeks, while work on scale insects on apples indicates that shelter belts of Pinus radiata are the cause of the trouble. Factors governing the need for potash top-dressing on New Zealand soils are also being studied as well as pruning systems for apples, the storage of apples in controlled atmospheres, the control of Verticillium wilt of tobacco and the general ecology of rabbits, while a survey at Lake Monk, Southern Fiordland, has contributed towards the understanding of the relations which have arisen between introduced animals and native forests.

\title{
THE DELHI ENGINEERING COLLEGE TRUST
}

$\underset{\mathrm{N}}{\mathrm{A}}$ T a meeting of the sponsors of the Delhi Engineering College Trust, held at Bowater House on November 16, the chairman, Sir William McFadzean, president of the Federation of British Industries, reviewed progress in the setting up of the College, in which H.M. Government, the Government of India and British industry are working together with the aim of establishing an outstanding institution for technical education.

Since January 1959, when Prince Philip laid the foundation stone of the College at Delhi, the Government of India has completed the administrative organization and has set up a governing body of which the chairman is Prof. M. S. Thacker, Permanent Secretary of the Indian Ministry of Scientific Research and Cultural Affairs. All preparations are in hand for the opening of the College during July 1961, on the magnificent Haus Kas site near Delhi.

The United Kingdom Government has undertaken to provide ten British professors for the College, who will advise the Indian professorial staff during the first five years. Four professors are already at Delhi, and three more are to be appointed this year.

Sir William also reported the success of the appeal to British industry for subscriptions to provide equip- ment for the College. The target figure of a quarter of a million pounds had been exceeded, thanks to 115 companies which had contributed over the past year. Over the next three years, as the buildings of the College are completed, the equipment for the successive stages of the five-year course is to be purchased on behalf of the Trust by the Crown Agents for Oversea Governments and Administrations.

Sir William then outlined the desirability, after the College was established, of offering continuing academic and practical support for it from the United Kingdom Government, British industry, and British universities and colleges. This was a matter to which the sponsors would be invited to give further attention when the time was ripe. In the meantime, the progress that was being made in all preparations for the opening of the College held out good promise for its future as a centre of advanced education in engineering in India.

Sir Eric Coates, chairman of the Executive Committee of the Trust, described how the most modern equipment for the College was being selected, in accordance with the advice of an academic working party under the chairmanship of Prof. S. R. Sparkes, of the Imperial College of Science and Technology; and 
how other aspects of the project were developing in accordance with the programme of the Indian Government.

Sir Willis Jackson, as chairman of the Technical Sub-Committee of the Trust, referred to the difficulties at the present time of finding the right calibre of man for professorial posts. He emphasized the need for further help by British industry, perhaps by endowing chairs at the College, and also by facilitating the secondment of experts in specialist fields of technology for short periods to assist in the conduct of postgraduate courses and in stimulating research.

Sir Algernon Rombold, Deputy Under-Secretary of State, Commonwealth Relations Office, said that satisfaction at the response to the sponsors' appeal would be widely shared, and that the project was an outstanding example of co-operation between the Governments of India and the United Kingdom and
British industry. He endorsed the hope that a recognized system of secondment by industry and universities would be developed to meet the growing need for experts for overseas service.

Sir Alexander Fleck said that the vigour of the work of the Trust's officers showed that the special problems presented by any tripartite project of this nature were being solved in a satisfactory way. $\mathrm{He}_{e}$ believed that the continued support of British industry would be readily forthcoming for the project on the lines which Sir William McFadzean had sketched out. This would be true both in the immediate future and over the years as the project developed.

Among the other sponsors present were Sir Hugh Beaver, Sir Leslie Gamage, Mr. S. E. Goodall, Sir Kenneth Hague, Sir Harry Jephcott, Prof. Sutton Pippard and Mr. Whitney Straight. Other sponsors who were unable to attend were represented.

\section{THE ROBERTSON CREEK SPAWNING CHANNEL}

$\mathrm{M}$ UCH of a recent issue of the Canadian Fish Culturist (No. 27, 1960) is given up to accounts by $K$. C. Lucas and D. Mackinnon of a man-made spawning channel which has just been built by the Fish Culture Development Branch of the Department of Fisheries of Canada in Robertson Creek. This is a secondary outlet of Great Central Lake, which lies near Port Alberni on Vancouver Island, British Columbia.

The design of this new artificial spawning channel is based on the experience gained in the construction and operation of an artificial spawning channel on Jones Creek, near Hope, British Columbia, which was made in 1954. The Jones Creek channel was constructed to save the salmon stocks in a stream threatened by the diversion of the flow because of hydro-electric development, but the Robertson Creek channel is the first such channel to be built primarily as a fisheries development project. Robertson Creek is an exceptionally favourable area for such a project, because works for the complete control of flows already existed, no provision for flood-flows was necessary, silting of the spawning beds by the incoming water seemed unlikely, the temperature of the stream remained moderate and the area was readily accessible.

The total length of Robertson Creek is 4,200 ft., and $2,550 \mathrm{ft}$. have been developed as a spawning channel. The gradient of the natural stream bed was greater than that needed for the spawning channel, so four drop-structures have been provided to localize the unwanted drop. Near the head of the spawning channel and a short distance below Great Central Lake is a downstream migrant diversion structure, which allows migrants passing out of Great Central Lake to be diverted into a flume which runs alongside the spawning channel to enter the latter just below drop strueture 3 . If it were found necessary in the future, this diversion flume could be extended downstream so as to bypass the lower spawning area. The first three drop-structures downstream from the diversion structure are similar in design and are relatively simple structures. Inclined plane traps are provided at each so that downstream migrants can be counted, and each incorporates a pool and weir-type fishway to provide for the upstream movements of adults if desired The lowermost drop-structure (4) is larger and more complex, because it incorporates a fish holding and collection system, and there is an observation chamber built into the side of the fishway.

A number of rearing ponds have been built at one side of the channel near its upper end, and these have been specially designed to allow maximum flexibility. Another additional structure is of par. ticular interest; this is an experimental test-flume, approximately $150 \mathrm{ft}$. long and $30 \mathrm{ft}$. wide, which lies in the channel a short distance below drop structure 3. Plans were made to construct this flume before it was decided to make the channel, and the Fisheries Research Board of Canada has contributed to its cost. This flume will be used for tests of fry and smolt guiding devices and for funda. mental work on the physiology of adult salmon.

Previous work on the survival of Pacific salmon eggs and alevins has shown that the percentage survival varies widely, but is usually low (less than 10 per cent). The results of the first transplant of pink salmon eggs in the Robertson Creek spawning channel are therefore particularly encouraging More than one and a half million pink salmon were planted, at the eyed stage, during the latter half of November and the first days of December 1959. The first fry was trapped on March 15, 1960, but nearly all the fry migrated during the first three weeks of April and, when the last batch recorded migrated, during the night of April 21-22, the total represented roughly 95 per cent of the eyed eggs planted.

This artificial spawning channel is clearly a very important site for experimental investigations of many aspects of the biology of various stages in the life-history of Pacific salmon. Judged as a piece of experimental equipment, it is not cheap. To date, more than $£ 81,000$ has been spent on the channel, the experimental flume and the small field camp which has been built near the lower end of the channel. T.t is becoming increasingly clear, however, that many problems of salmon biology cannot be solved unless adequate experimental facilities can be provided, and there is good reason to suppose, therefore, that this outlay will prove to be money well spent. 